\title{
Improved performance of polymer electrolyte membrane fuel cells with modified micro porous layer structures
}

[Manuscript for Energy Technology / Wiley]

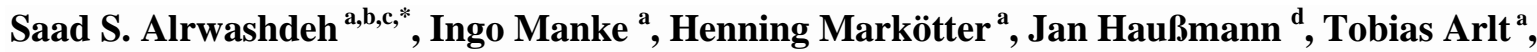
André Hilger a , A. M. Al-Falahat ${ }^{\text {a,b,c }}{ }^{\text {, Merle Klages }}{ }^{\text {d }}$, Joachim Scholta ${ }^{\text {d }}$, John Banhart ${ }^{\text {a,c }}$
\end{abstract}

\section{Graphical Abstract}

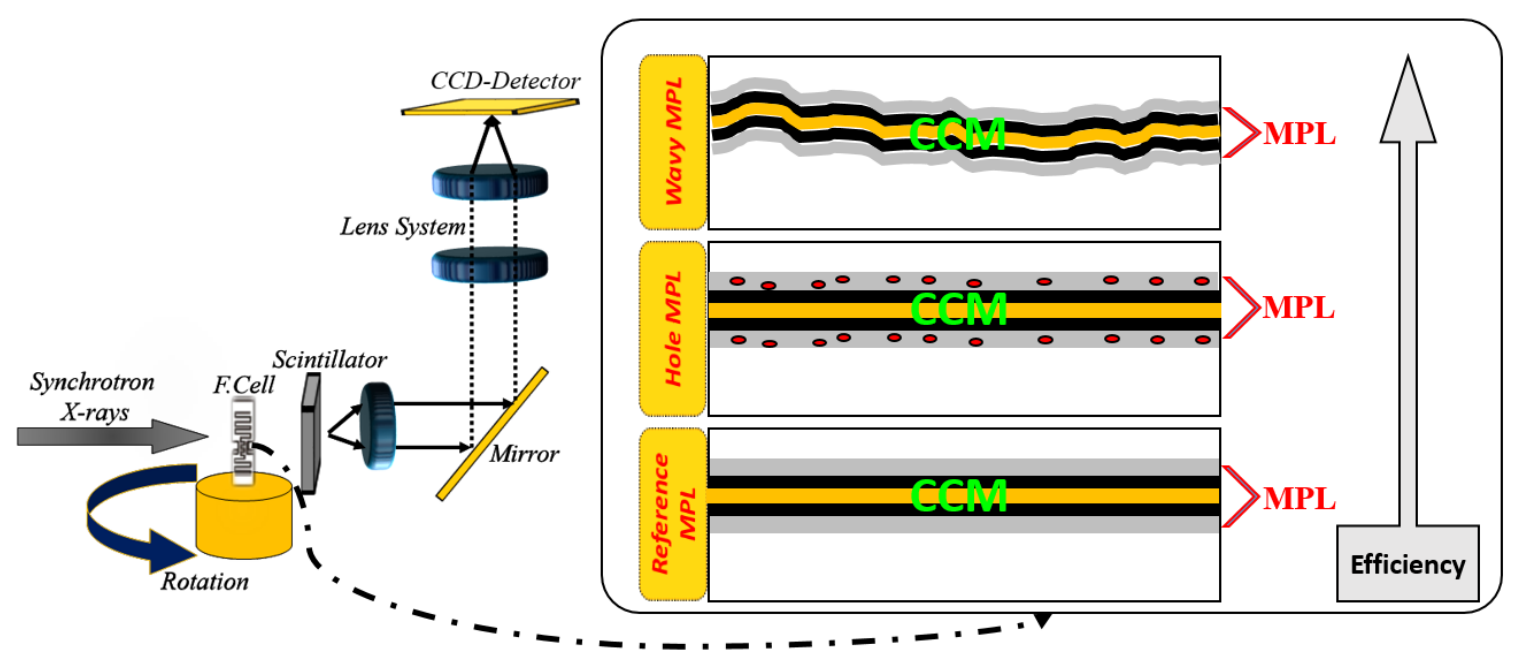

Three different types of MPLs are compared: A reference MPL material, an MPL with wavy structure, and an MPL with randomly distributed holes. We found a strong impact of the modified MPL structure on the water distribution at operating temperatures of 40 and $55^{\circ} \mathrm{C}$ and an increase of cell performance up to $14 \%$ compared to the reference cell.

\footnotetext{
Abstract

A possible way to improve membrane humidity conditions in polymer electrolyte membrane fuel cells and, therefore, the cell performance is the optimization of micro porous layer structures. In this work, water transport in modified micro porous layer (MPL) materials in polymer electrolyte membrane fuel cells (PEMFCs) was investigated by in-operando synchrotron X-ray tomography. Three different types of MPLs are compared: A reference standard MPL material, an MPL material with a special wavy structure, and an MPL with randomly distributed holes. We found a strong impact of the modified MPL structure on the water distribution at operating temperatures of 40 and $55^{\circ} \mathrm{C}$ and an increase of cell performance up to $14 \%$ compared to the reference cell. We assume the water distribution at the membrane to be responsible for the performance increase and provide a detailed discussion.
} 


\section{Introduction}

Fuel cell technology is one of the most promising solutions for future mobile and stationary energy supplies. Polymer electrolyte membrane fuel cells (PEMFC) have benefits related to reliability, efficiency and flexibility, which is why they are considered one of the most appropriate candidates for the mobile sector $^{[1-6]}$. The water distribution during operation is one of the most important issues in the development of PEMFC. Through the reaction of hydrogen and oxygen, water is formed, that can be used to humidify the membrane, but that can also hinder the gas supply of the catalyst layer. As a result, studying the water transport in PEMFCs is crucial to optimize water management and to maintain a stabilized water distribution and cell performance ${ }^{[7]}$.

General improvement of water distribution and transport in PEMFCs is a challenging aim due to the high number of parameters affecting the operation conditions. In the recent years, related investigations have been sharply increasing and the used investigation methods as well as the cell designs were optimized for this purpose. These works strongly supported a proper understanding of the water distribution and transport phenomena.

The important issue of water management is related to the generation, distribution and transport of liquid water since cell efficiency, performance and long-term stability crucially rely on the hydration level of the membrane and the free flow of supply gases.

[a] Saad S. Alrwashdeh, Dr. Ingo Manke Dr. Henning Markötter, Dr.

Tobias Arlt, Dr. André Hilger, A. M. Al-Falahat and Prof. Dr. John

Banhart

Helmholtz Centre Berlin for Materials and Energy

Hahn-Meitner-Platz 1

14109 Berlin, Germany

E-mail: saad.alrwashdeh@helmholtz-berlin.de

[b] Saad Sabe Alrwashdeh and A. M. Al-Falahat

Mechanical Engineering Department

Faculty of Engineering, Mu'tah University

P.O Box 7, Al-Karak 61710 Jordan

[c] Saad S. Alrwashdeh, A. M. Al-Falahat and Prof. Dr. John Banhart

Institute of Material Science and Technologies

Technical University Berlin

10623 Berlin, Germany

[d] Jan Haußmann, Merle Klages and Joachim Scholta

Zentrum für Sonnenenergie- und Wasserstoff-Forschung Baden

Württemberg (ZSW)

Helmholtzstraße 8

89081 Ulm, Germany

It has been observed that the variability of operating conditions such as temperature, pressure, relative humidity (RH) and reactant gas stoichiometries can significantly affect fuel cell performance. Optimizing operating conditions via modeling approaches as well as experiments with varying operating temperature, relative humidities and gas stoichiometries have been conducted in order to effectively optimize electrode kinetics, membrane hydration, liquid and gas transfer processes and catalyst layer durability ${ }^{[8-17]}$. 
Several imaging techniques were employed in PEMFC research to extend the understanding of physical phenomena related to fuel cell performance ${ }^{[18,19]}$. Imaging techniques have various objectives in the field of energy related materials such as characterization of the dynamic behavior under varied operating conditions as well as revealing structural properties of these materials ${ }^{[20,21]}$. Among the techniques used for water management studies of PEMFCs are X-ray and synchrotron X-ray imaging ${ }^{[22-31]}$, magnet resonance tomography ${ }^{[32-34]}$ and neutron imaging ${ }^{[35-48]}$. These techniques allow for visualizing water distributions under varying operating conditions and to quantify the water content.

The modified microporous layer (MPL) plays a major role for the water distribution in the gas diffusion layers and at the membrane. In this work one reference and two modified MPLs are assembled in a cell and studied in operando with synchrotron X-ray tomography in order to investigate the effect of MPL modification on the water distribution.

In the past decades a variety of different fuel cell types were improved and developed, which are categorized depending on the operating temperature and electrolysis material. The polymer electrolyte membrane fuel cell (PEMFC), also known as proton exchange membrane fuel cell, is considered among the most prevalent type of fuel cells. Figure 1 shows a scheme of the PEMFC setup with all parts such as: catalyst layer, flow field and gas diffusion layer GDL.

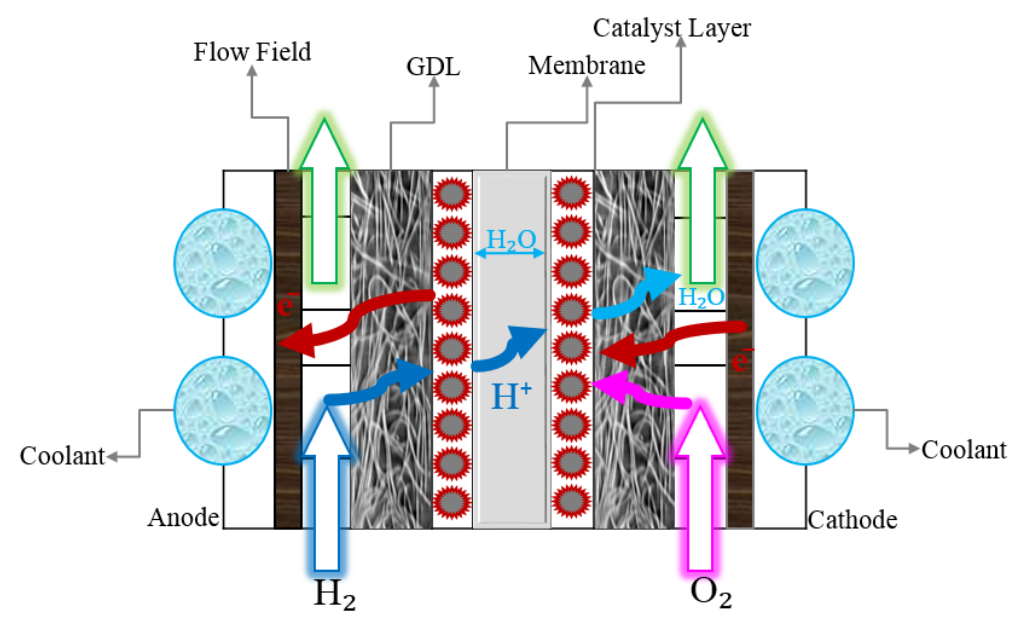

Figure 1. Scheme of a polymer electrolyte membrane fuel cell (PEMFC).

The general functional principle of a PEM fuel cell refers to an electrochemical battery or galvanic cell, with the specific characteristic of spatial separation of fuel storage and energy generation. Fuel gases are stored outside the cell and are fed to the reaction area only when electric power generation is required.

For this study three fuel cells were designed and fabricated by the Center for Solar Energy and Hydrogen Research, Ulm (ZSW): 1. A cell with a reference membrane electrode assembly (MEA) material, 2. A cell with a modified gas diffusion layer (GDL) with a wavy MPL material and 3. A cell with randomly 
distributed holes in the MPL. The reference cell contained a CCM equipped with a H1410 I4 C10 GDL while the other cells were equipped with material based on a H1410 and a H1411, respectively. The thickness of these GDLs are 168, 166 and $201 \mu \mathrm{m}$ with porosities of 68, 67 and $73 \%$, respectively. Figure 2 shows the fuel cell cross-sections and corresponding schematic drawing. The cell with a straight MPL is considered as reference cell (A), the modified cells are characterized by a wavy MPL (C) and by holes in the MPL (E). The corresponding schematic of the reference, wavy and hole MPLs is found in figure 2 (B, $\mathrm{D}$ and $\mathrm{F})$.
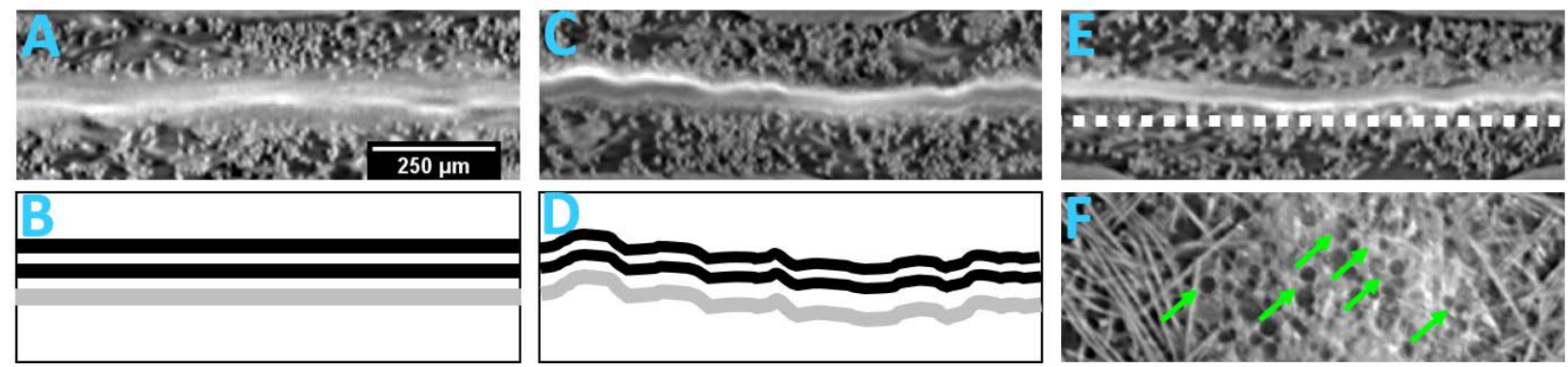

Figure 2. A, C, E: Tomographic and schematic cross-sections of the studied PEMFCs. B and D are a schematic drawing of A and C, F shows the corresponding in-plane slice through the MPL on the cathode side of E.

\section{Results and Discussion}

Table. 1 shows the obtained voltages in $\mathrm{mV}$ of the reference, first and second modified cells at a current density of $1 \mathrm{~A} / \mathrm{cm}^{2}$. Accordingly, the first modified cell containing the wavy MPL material shows a slightly higher performance than the cell with reference MPL material at both temperatures.

Table. 1 The reference, first and second modified cell voltages measured at $1 \mathrm{~A} / \mathrm{cm}^{2}$

\begin{tabular}{|c|c|c|c|c|}
\hline \multicolumn{2}{|c|}{ Cell type } & Reference cell & Wavy MPL cell & Hole MPL cell \\
\hline 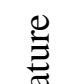 & $40^{\circ} \mathrm{C}$ & $500 \mathrm{mV}$ & $570 \mathrm{mV}$ & $567 \mathrm{mV}$ \\
\hline 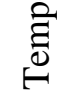 & $55^{\circ} \mathrm{C}$ & $525 \mathrm{mV}$ & $567 \mathrm{mV}$ & $544 \mathrm{mV}$ \\
\hline
\end{tabular}

The cells were tomographed before operation to create a reference state without water. This tomography is later subtracted from the state after operation containing product water in order to extract the water distribution. During cell operation membrane swelling occurs and displace the surrounding GDL material, which results in a slightly different shape of the GDL. Therefore, a mathematical algorithm conducting a 3D morphology correction based on the linear Pearson correlation coefficient is used. Figure 3. shows exemplary about how this subtraction procedure works. Through this example it is clear that the water segmentation depends on the difference between the operation and dry states (A-B), and reflects the distribution of water and therefore, the amount of water in the cell (D).This can be followed through the red arrows in the Figure 3. The water saturation can be calculated through the division of the water volume fraction by the pore volume fraction in selected regions of the cell. 


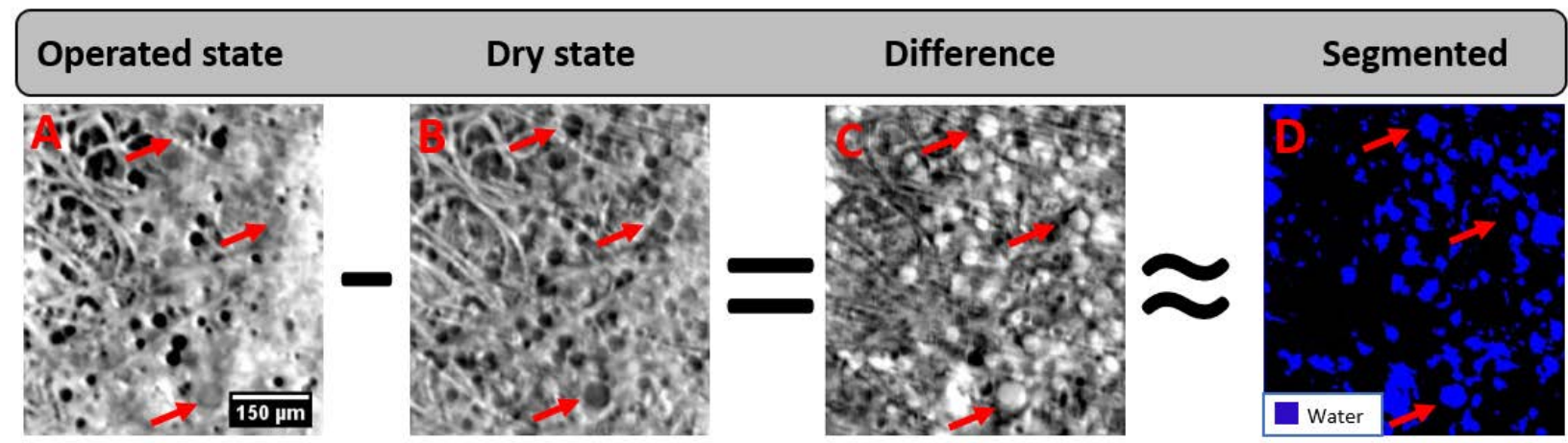

Figure 3. Difference of the dry reference state (B) from the operating state (A) to achieve water extraction (C) and to finally segment water (D).

Exemplarily, we present results of the reference cell in Figure 4 at two operation temperatures namely 40 ${ }^{\circ} \mathrm{C}$ and $55{ }^{\circ} \mathrm{C}$ (A-C and G-I) and (D-F and J-L) respectively, in three positions in the GDL, which are close to the channels (A, D, G and J), in the middle of the GDL (B, E, H, and K) and close to the catalyst (C, F, I and L) each for anode (A-F) and cathode (G-L).

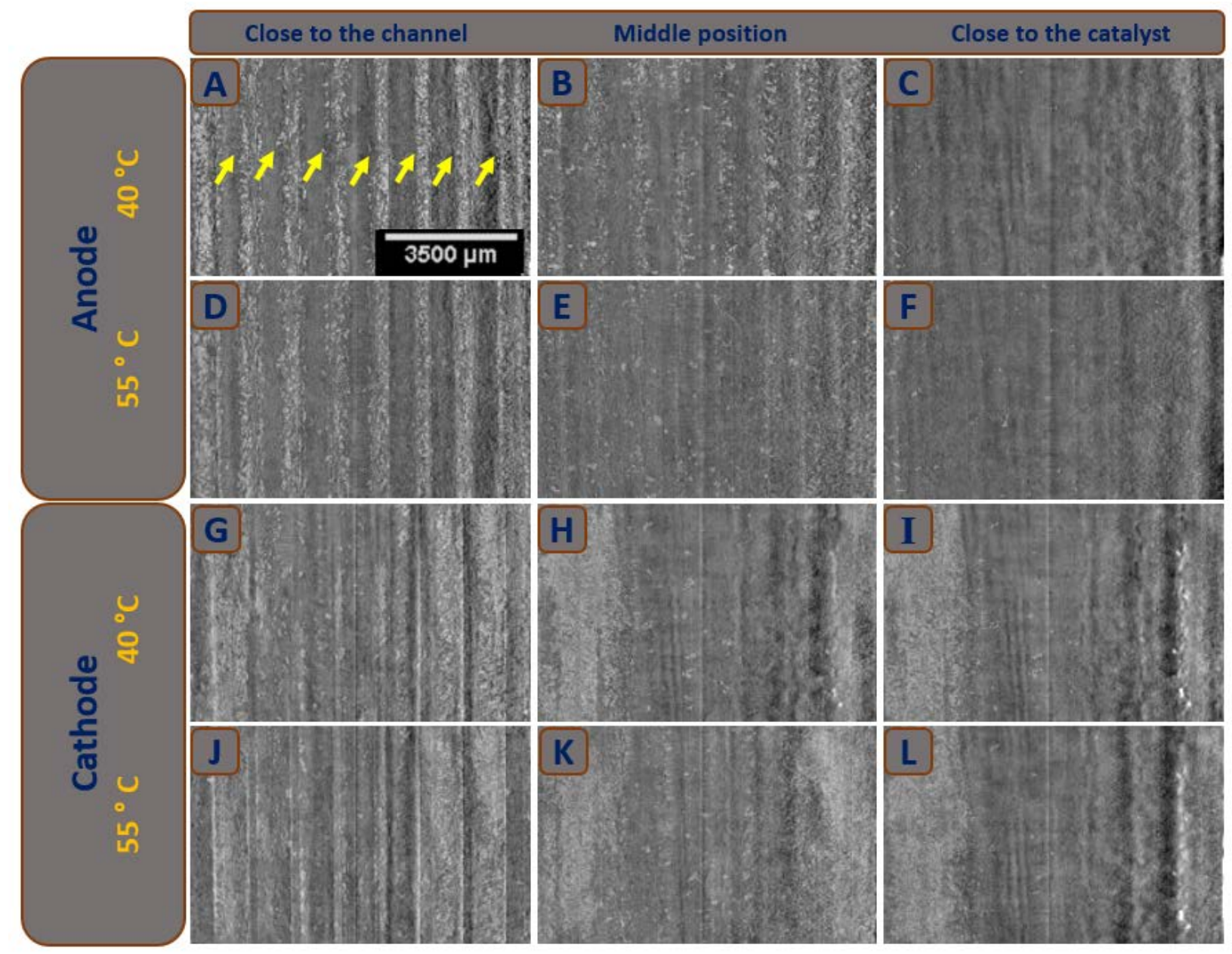

Figure 4. Water distribution at three positions in the reference cell (close to the channel, middle position and close to the catalyst) for both the anode and cathode sides at both operation temperatures $\left(40\right.$ and $\left.55^{\circ} \mathrm{C}\right)$. 
It can be observed in Figure 4 that at the first position close to the channel (Figure 4A, D, G and J) more water is distributed in the rib region than in the channel region. This applies to the anode and cathode side (for example yellow arrows). The amount is less for the high temperature. Finally, at the position close to the catalyst, the anode side appears almost dry at both operating temperatures (Figure $4 \mathrm{G}$ and F) while the cathode side exhibits accumulations at both operating temperatures.

Figure 5 (A-F) shows profiles of the water saturation in the reference and modified materials in the channel and rib regions, separately on the anode and cathode sides at the two operation temperatures, 40 and $55^{\circ} \mathrm{C}$. Figure 5 (A-B) shows the water saturation of the reference cell at the channels and ribs of the anode and cathode sides separately. The water saturation of the anode GDL at the channels at $40{ }^{\circ} \mathrm{C}$ is slightly more than at $55^{\circ} \mathrm{C}$ (about $5 \%$ ), while the water saturation of the anode GDL beneath the ribs is approximately the same. The water saturation at the cathode channels is similar for the channel and rib regions at both operating temperatures, while the water saturation of the cathode beneath the ribs at $40^{\circ} \mathrm{C}$ is slightly higher (about $4 \%$ ) than at $55^{\circ} \mathrm{C}$.

In case of the wavy MPL material water saturation at the anode side in the channel region at $40{ }^{\circ} \mathrm{C}$ is about $8 \%$ higher than at $55^{\circ} \mathrm{C}$ (see Figure 5C), while it is approximately the same for both temperatures beneath the anode ribs (see Figure 5D). Water saturation at the cathode beneath the channels is slightly higher at $40^{\circ} \mathrm{C}$ than at $55^{\circ} \mathrm{C}$ see Figure $5 \mathrm{C}$, while the saturation in the material at the cathode ribs is approximately the same at both operating temperatures see, Figure 5D.

Figure 5(E-F) shows the water saturation in the material containing MPL holes. The GDL in the rib region is higher saturated at $55{ }^{\circ} \mathrm{C}$ than at $40{ }^{\circ} \mathrm{C}$. The water saturation at the cathode at $40{ }^{\circ} \mathrm{C}$ is exceptional high for both, channel and rib regions. It becomes much less at higher temperature. 

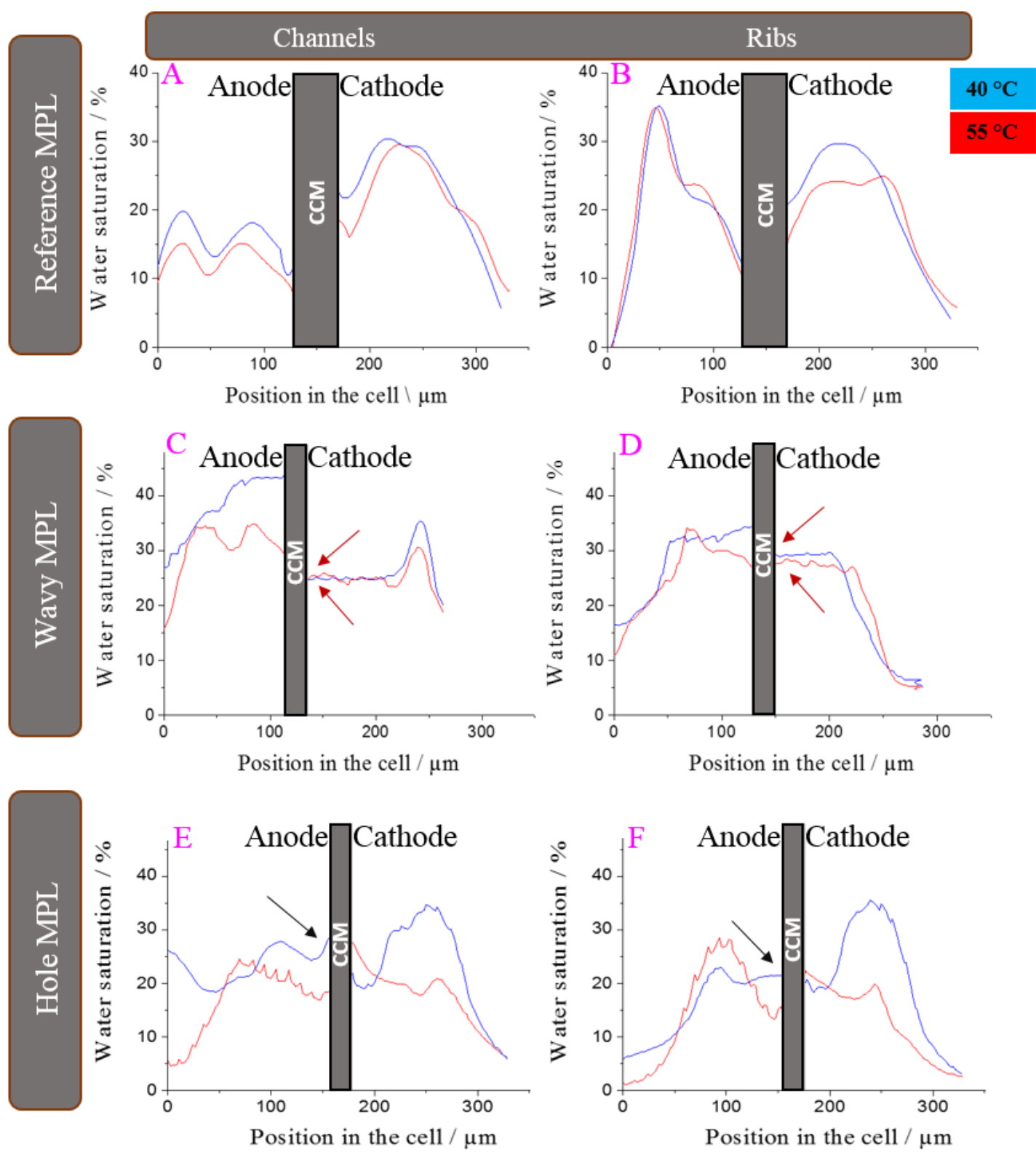

Figure 5. Water saturation for channels and ribs of the anode and cathode in the GDL for reference MPL (A-B), the GDL with a wavy MPL (C-D) and for the GDL with holes in the MPL (E-F), all at the two operation temperatures of $40^{\circ} \mathrm{C}$ and $55^{\circ} \mathrm{C}$.

The overall water production rate (defined by the current density) was the same for all cell materials used and for both operating temperatures. However strong differences were found in the amount of agglomerated water and its distribution.

First of all, a strong influence of the temperature on the water distribution was found. This not only applies to the entire cell temperature, which was set to 40 and $55^{\circ} \mathrm{C}$. Local temperature gradients affect the water distribution as well. The most important effect is caused by the flow field ribs (see Fig. 4). Smaller scale temperature gradients on each rib/channel interface result in water agglomerations in the GDL at the rib structure. Therefore, the temperature in the GDL decreases from the catalyst layer to the 
rib structure. This is in line with recent literature that showed an influence of the rib structure on the water distribution in the GDL ${ }^{[49]}$.

Next we want do analyze the correlation between performance increase and water distribution. In general: The material with the wavy MPL shows the best performance with up to $14 \%$ higher cell voltage compared to the reference material (see. Table 1).

Wavy MPL at $40^{\circ} \mathrm{C}$ :

The water amount at the cathode is about the same as in the reference material, but much more homogenously distributed (see Figure 5 D). In Figure 6C and D, a rather flat water saturation curve on the cathode side beginning from the membrane nearly up to the channel/rib structure is found. Furthermore, close to the membrane much more water is found (about $30 \%$ beneath the ribs and about $8 \%$ beneath the channels) (see red arrows in Figure $5 \mathrm{C}$ and D) compared to the reference material. This effect is even stronger at the anode side, where more than twice as much water is found close to the membrane.

The wavy shape with a varying MPL thickness seems to increase water condensation and accumulation close to the membrane, which might contribute to a better membrane humidification. Possibly, water diffusion through the thinner areas of the Wavy MPL is higher compared to a standard MPL with an approximately constant thickness. These thin areas cause the water to move closer to the membrane at certain spots and could be the reason a better water supply of the membrane. Furthermore, water transport from the membrane to the channel may be better due to the formation of water transport channels that leave large parts of the material with less water. This yields a better gas supply for the catalyst. This assumption is also supported by recent findings of Markötter et al. ${ }^{[50,51]}$.

Both effects, the higher membrane humidification and the better water transport through the GDL, could at least partially explain the measured increase in performance by about $14 \%$ (see table 1 ).

On the anode side about $20 \%$ more water is found at $40{ }^{\circ} \mathrm{C}$ than in the reference material, which could be caused by a higher back diffusion, what corresponds which the assumption of a generally higher humidification level of the membrane.

Wavy MPL at $55^{\circ} \mathrm{C}$ :

At $55^{\circ} \mathrm{C}$, the wavy MPL material is again the best performer with an about $8 \%$ higher voltage than for the reference material. The water amount for the cathode shows the similar behavior as at $40{ }^{\circ} \mathrm{C}$ : A much more homogenous water distribution compared to the reference MPL. Slightly less (about 2\%) liquid water was found than at $40{ }^{\circ} \mathrm{C}$, except at the anode beneath the channels. Where we found significantly more water (about 25\%) compared to the results at $40{ }^{\circ} \mathrm{C}$ operating temperature. Most highly the performance increase at $55^{\circ} \mathrm{C}$ has similar reasons as at $40^{\circ} \mathrm{C}$. 
Hole MPL at $40^{\circ} \mathrm{C}$ :

The behavior of the hole MPL material is very different to that of the wavy MPL. The water distribution at the cathode side is about the same for the channel and rib regions with a significant lower saturation value close to the membrane (about 30\%) than in the central area of the GDL (see Figure $5 \mathrm{E}$ and F). This is somehow similar to what is found for the reference MPL.

On the anode side, the water distribution for the channel and rib regions are similar. However, the water amount close to the membrane is much higher compared to the reference cell (about 70\% beneath the ribs and about 150\% beneath the channels) (see black arrow Figure 5 E and F), although still significantly lower than for the wavy MPL.

The holes in the MPL may work in a similar way as the inhomogeneous wavy MPL. They serve as agglomeration spots for liquid water and keep the membrane better humidified and support the overall water transport from the membrane to the channels during cell operation. This is an agreement with recent studies on perforation holes by Alrwashdeh et al. and others ${ }^{[52-57]}$, where water agglomerations in the MPL holes were found, or to findings by Markötter et al, where cracks have been found to yield as seeding spots for 3D transport paths ${ }^{[51,58]}$.

Compared to the wavy MPL, the overall water amount on the cathode side is a little higher (5\%) while it is much less at the anode side. Water back diffusion seems to be less strong in the hole MPL. However, performance is about the same as for the wavy MPL (table 1).

Hole MPL at $55^{\circ} \mathrm{C}$ :

Going from $40{ }^{\circ} \mathrm{C}$ to $55{ }^{\circ} \mathrm{C}$, the large water amount in the central area on the cathode side largely disappears and is reduced to about half of its initial value. However, the water amount directly at the membrane is not affected and even slightly increased, while it decreases at the anode side. Again, we can suspect a better membrane humidification to be partially responsible for the performance increase that is only $3.6 \%$ in this case.

It may be concluded that the performance increase is mainly caused by water agglomeration close to the membrane while water in the central part of the GDL seems to have less influence.

\section{Conclusions}

We presented an investigation of the water distribution in PEM fuel cells containing GDL materials with modified MPLs. Two differently structured MPLs were employed: a wavy shaped MPL and an MPL with randomly distributed holes. We found an increase of the cell performance by up to $14 \%$ for the wavy shaped MPL and by up to $13 \%$ for the hole MPL. We conclude that a significant part of the performance increase can be attributed to the specific water distribution. 
Synchrotron X-ray tomography has shown that compared to a non-modified reference material, water agglomerations directly at the proton-conductive membrane and the homogeneity of the water distribution within the GDL are strongly changed when using the modified MPL materials.

The correlation between water distribution and performance is very complex and affected by many factors. With this work we have given first insights into the complexity of the structure-property relationships between MPL structure, water distribution and overall cell performance. Future work will focus on a large variety of other structural and morphological modifications of MPL materials that may lead to even better fuel cell performance.

\section{Experiments Section}

Fuel cell operation was held at a current density of $1 \mathrm{~A} / \mathrm{cm}^{2}$ at stoichiometric ratios of 5 at both the cathode and anode side. Cell temperatures of $40^{\circ} \mathrm{C}$ and $55^{\circ} \mathrm{C}$ were used. The corresponding results are compared in this study.

The cells were investigated by synchrotron X-ray tomography of a region in the middle of the cell covering $\sim 10 \%$ of the total active area. The setup is illustrated in Figure 6.

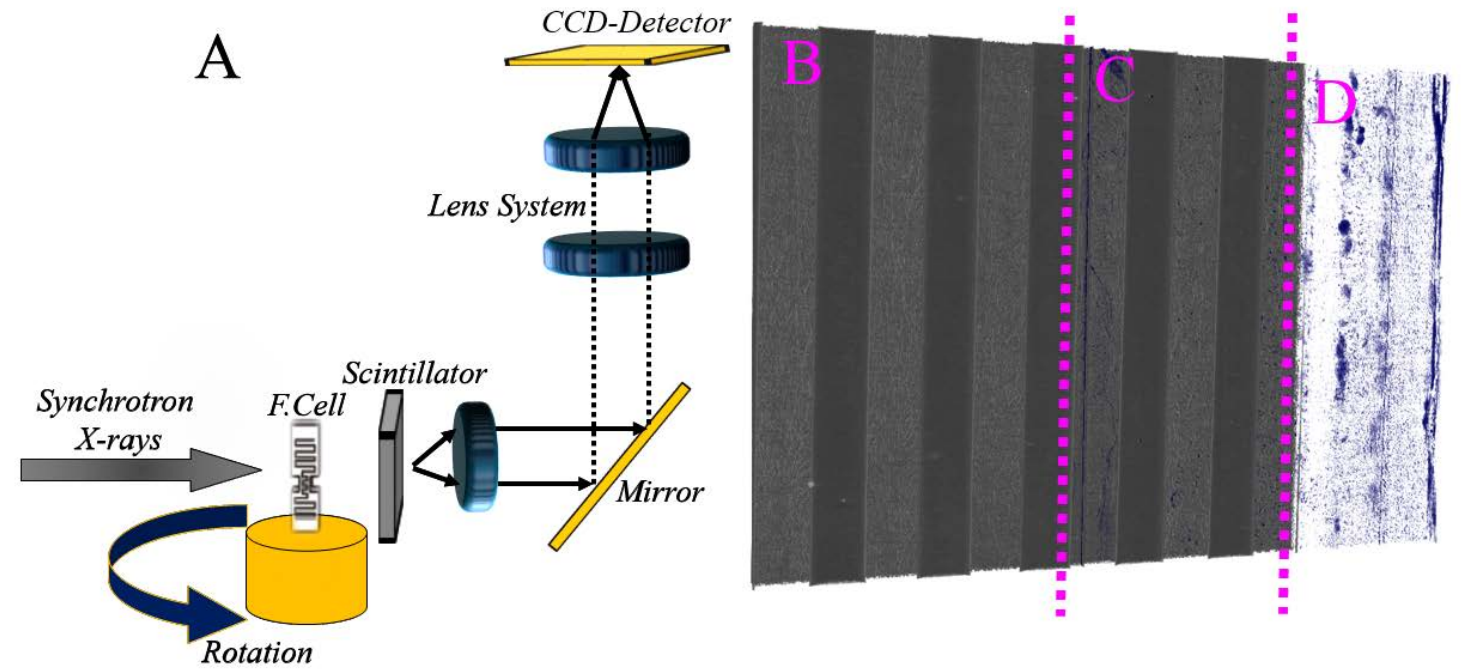

Figure 6. Scheme of the synchrotron tomography setup (A), tomography image of the dry cell (B), tomography image of the operating cell (C) and water distribution in the cell (D).

The measurements were performed at the imaging beamline "BAMline" at the electron storage ring Bessy II in Berlin, Germany. The used PCO400 CCD detector had 4008 x 2672 pixels. Together with the applied optic (Optique Peter) this resulted in pixel sizes of $2.2 \mu \mathrm{m} \times 2.2 \mu \mathrm{m}$ and a corresponding field of view of $8.8 \mathrm{~mm}$ x $5.9 \mathrm{~mm}$. During radiography, images were acquired with an exposure time of $2 \mathrm{~s}$. Tomographies were acquired with 3600 projection images over an angular range of $360^{\circ}$ within a total acquisition time of about $2.5 \mathrm{~h}$. A photon energy of $19 \mathrm{keV}$ was selected using a W/Si double multilayer 
monochromator with an energy resolution of $\Delta \mathrm{E} / \mathrm{E} \sim 1.5 \%$. The chosen energy ensures sufficient beam transmission through the cell materials while still maintaining adequate contrast to water ${ }^{[59]}$.

Beam transmission was calculated via image processing with flat field images containing the plain beam

without the cell and dark field images without beam ${ }^{[18]}$. First the cells were tomographed in the dry condition. Then, during operation, the cells were radiographed to capture the transport dynamics of the evolving liquid product water in the cell components. After these dynamic radiographic experiments, cell operation was stopped, tubes unplugged, connections sealed and the cell tomographed in order to capture the water distribution inside the fuel cell components. This combination of techniques allows for a detailed analysis of the transport dynamics during operation, which are captured in the radiographic projection data, with the three-dimensional structure of the cell materials as well as the threedimensionally resolved water distribution during operation at a given time.

\section{Acknowledgements}

We gratefully acknowledge the funding of the project Optigaa 2 (grant number 03ET6015A) by the Federal Ministry of Economic Affairs and Energy (BMWi.IIC6).

Keywords: polymer electrolyte membrane fuel cell; synchrotron X-ray tomography; water distribution; MPL materials

\section{References}

[1] W. Vielstich, A. Lamm, H. A. Gasteiger in Handbook of Fuel Cells - Fundamentals, Technology and Applications, Vol. 3 (Ed.^^ds.: Editor), John Wiley \& Sons, City, 2003.

[2] C.-Y. Wang in Two-phase flow and transport, Vol. 3 (Eds.: W. Vielstich, A. Lamm, H. A. Gasteiger), John Wiley \& Sons, Chichester, 2003, pp.337-347.

[3] G. Hoogers in Fuel Cell Technology Handbook, Vol. (Ed.^Eds.: Editor), CRC Press LLC, City, 2003.

[4] C. Hartnig, C. Roth, Polymer Electrolyte Membrane and Direct Methanol Fuel Cell Technology, Volume 2: In Situ Characterization Techniques for Low Temperature Fuel Cells, Woodhead Publishing Limited, 2012.

[5] J. Garche, C. K. Dyer, P. T. Moseley, Z. Ogumi, D. A. J. Rand, B. Scrosati in Encyclopedia of Electrochemical Power Sources, Vol. 3, Elsevier, Amsterdam, 2009, pp.4538.

[6] L. Carrette, K. A. Friedrich, U. Stimming, Fuel Cells. 2001, 1, 5-39.

[7] P. K. Sinha, P. P. Mukherjee, C. Y. Wang, Journal of Materials Chemistry. 2007, 17, 3089-3103.

[8] P. K. Sinha, C.-Y. Wang, Electrochimica Acta. 2007, 52, 7936-7945.

[9] C. Y. Wang, P. Cheng, International Journal of Heat and Mass Transfer. 1996, 39, 3607-3618.

[10] U. Pasaogullari, C.-Y. Wang, J. Electrochem. Soc. 2005, 152, A380-A390.

[11] G. Gaiselmann, R. Thiedmann, I. Manke, W. Lehnert, V. Schmidt, Computational Materials Science. 2012, 59, 75-86.

[12] G. Gaiselmann, D. Froning, C. Tötzke, C. Quick, I. Manke, W. Lehnert, V. Schmidt, International Journal of Hydrogen Energy. 2013, 38, 8448-8460.

[13] G. Gaiselmann, C. Tötzke, I. Manke, W. Lehnert, V. Schmidt, Journal of Power Sources. 2014, 257, 52-64.

[14] T. Berning, N. Djilali, J. Electrochem. Soc. 2003, 150, A1589-A1598.

[15] M. Hu, A. Gu, M. Wang, X. Zhu, L. Yu, Energy Conversion and Management. 2004, 45, 1861-1882. 
[16] R. Thiedmann, I. Manke, W. Lehnert, V. Schmidt, Journal of Materials Science. 2011, 46, 7745-7759.

[17] A. Bazylak, V. Berejnov, B. Markicevic, D. Sinton, N. Djilali, Electrochimica Acta. 2008, 53, 7630-

7637.

[18] J. Banhart in Advanced Tomographic Methods in Materials Research and Engineering, Vol.

(Ed.^Eds.: Editor), Oxford University Press, City, 2008.

[19] I. Manke, H. Markötter, C. Tötzke, N. Kardjilov, R. Grothausmann, M. Dawson, C. Hartnig, S. Haas, D. Thomas, A. Hoell, C. Genzel, J. Banhart, Adv. Eng. Mater. 2011, 13, 712-729.

[20] T. Arlt, I. Manke, K. Wippermann, H. Riesemeier, J. Mergel, J. Banhart, Journal of Power Sources. 2013, 221, 210-216.

[21] C. Tötzke, G. Gaiselmann, M. Osenberg, J. Bohner, T. Arlt, H. Markötter, A. Hilger, F. Wieder, A. Kupsch, B. R. Müller, M. P. Hentschel, J. Banhart, V. Schmidt, W. Lehnert, I. Manke, Journal of Power Sources. 2014, 253, 123-131.

[22] I. Manke, C. Hartnig, M. Grünerbel, W. Lehnert, N. Kardjilov, A. Haibel, A. Hilger, J. Banhart, H. Riesemeier, Applied Physics Letters. 2007, 90, 1-3.

[23] W. Maier, T. Arlt, K. Wippermann, C. Wannek, I. Manke, W. Lehnert, D. Stolten, J. Electrochem. Soc. 2012, 159, F398-F404.

[24] T. Sasabe, P. Deevanhxay, S. Tsushima, S. Hirai, Journal of Power Sources. 2011, 196, 8197-8206.

[25] I. Manke, C. Hartnig, N. Kardjilov, H. Riesemeier, J. Goebbels, R. Kuhn, P. Krüger, J. Banhart, Fuel Cells. 2010, 10, 26-34.

[26] N. Khajeh-Hosseini-Dalasm, T. Sasabe, T. Tokumasu, U. Pasaogullari, Journal of Power Sources. 2014, 266, 213-221.

[27] J. Hinebaugh, J. Lee, A. Bazylak, J. Electrochem. Soc. 2012, 159, F826-F830.

[28] J. Lee, R. Yip, P. Antonacci, N. Ge, T. Kotaka, Y. Tabuchi, A. Bazylak, J. Electrochem. Soc. 2015, 162, F669-F676.

[29] Z. Fishman, J. Hinebaugh, A. Bazylak, J. Electrochem. Soc. 2010, 157, B1643-B1650.

[30] J. Eller, T. Rosen, F. Marone, M. Stampanoni, A. Wokaun, F. N. Buchi, J. Electrochem. Soc. 2011, 158, B963-B970.

[31] S. H. Eberhardt, F. Marone, M. Stampanoni, F. N. Buchi, T. J. Schmidt, J. Synchrot. Radiat. 2014, 21, 1319-1326.

[32] K. W. Feindel, L. P. A. LaRocque, D. Starke, S. H. Bergens, R. E. Wasylishen, J. Am. Chem. Soc. 2004, 126, 11436-11437.

[33] K. W. Feindel, S. H. Bergens, R. E. Wasylishen, J. Am. Chem. Soc. 2006, 128, 14192-14199.

[34] K. W. Feindel, S. H. Bergens, R. E. Wasylishen, ChemPhysChem. 2006, 7, 67-75.

[35] R. J. Bellows, M. Y. Lin, M. Arif, A. K. Thompson, D. Jacobson, J. Electrochem. Soc. 1999, 146, 1099 1103.

[36] R. Satija, D. L. Jacobson, M. Arif, S. A. Werner, Journal of Power Sources. 2004, 129, 238-245.

[37] A. B. Geiger, A. Tsukada, E. Lehmann, P. Vontobel, A. Wokaun, G. G. Scherer, Fuel Cells. 2003, 2, 9298.

[38] P. Boillat, D. Kramer, B. C. Seyfang, G. Frei, E. Lehmann, G. G. Scherer, A. Wokaun, Y. Ichikawa, Y. Tasaki, K. Shinohara, Electrochemistry Communications. 2008, 10, 546-550.

[39] I. Manke, C. Hartnig, M. Grunerbel, J. Kaczerowski, W. Lehnert, N. Kardjilov, A. Hilger, J. Banhart, W. Treimer, M. Strobl, Applied Physics Letters. 2007, 90, 184101.

[40] C. Hartnig, I. Manke, N. Kardjilov, A. Hilger, M. Grünerbel, J. Kaczerowski, J. Banhart, W. Lehnert, Journal of Power Sources. 2008, 176, 452-459.

[41] H. Markotter, I. Manke, R. Kuhn, T. Arlt, N. Kardjilov, M. P. Hentschel, A. Kupsch, A. Lange, C. Hartnig, J. Scholta, J. Banhart, Journal of Power Sources. 2012, 219, 120-125.

[42] C. Totzke, I. Manke, A. Hilger, G. Choinka, N. Kardjilov, T. Arlt, H. Markotter, A. Schroder, K. Wippermann, D. Stolten, C. Hartnig, P. Kruger, R. Kuhn, J. Banhart, Journal of Power Sources. 2011, 196, 4631-4637.

[43] A. Lange, A. Kupsch, M. P. Hentschel, I. Manke, N. Kardjilov, T. Arlt, R. Grothausmann, Journal of Power Sources. 2010, 196, 5293-5298. 
[44] M. A. Hickner, N. P. Siegel, K. S. Chen, D. S. Hussey, D. L. Jacobson, M. Arif, J. Electrochem. Soc. 2008, 155, B427-B434.

[45] J. Park, X. Li, D. Tran, T. Abdel-Baset, D. S. Hussey, D. L. Jacobson, M. Arif, International Journal of Hydrogen Energy. 2008, 33, 3373-3384.

[46] M. Arif, D. L. Jacobson, D. S. Hussey in Neutron Imaging Study of the Water Transport in Operating Fuel Cells, Vol., 2006, pp.875-877.

[47] S. Gossling, M. Klages, J. Haussmann, P. Beckhaus, M. Messerschmidt, T. Arlt, N. Kardjilov, I. Manke, J. Scholta, A. Heinzel, Journal of Power Sources. 2016, 306, 658-665.

[48] M. Klages, S. Enz, H. Markotter, I. Manke, N. Kardjilov, J. Scholta, Journal of Power Sources. 2013, 239, 596-603.

[49] P. Krüger, H. Markötter, J. Haussmann, M. Klages, T. Arlt, J. Banhart, C. Hartnig, I. Manke, J. Scholta, Journal of PowerSources. 2011, 196, 5250-5255.

[50] H. Markotter, J. Haussmann, R. Alink, C. Totzke, T. Arlt, M. Klages, H. Riesemeier, J. Scholta, D. Gerteisen, J. Banhart, I. Manke, Electrochemistry Communications. 2013, 34, 22-24.

[51] H. Markötter, I. Manke, P. Krüger, T. Arlt, J. Haussmann, M. Klages, H. Riesemeier, C. Hartnig, J. Scholta, J. Banhart, Electrochemistry Communications. 2011, 13, 1001-1004.

[52] S. S. Alrwashdeh, H. Markötter, J. Haußmann, T. Arlt, M. Klages, J. Scholta, J. Banhart, I. Manke, Energy. 2016, 102, 161-165.

[53] D. Gerteisen, T. Heilmann, C. Ziegler, Journal of Power Sources. 2008, 177, 348-354.

[54] R. Alink, J. Haußmann, H. Markötter, M. Schwager, I. Manke, D. Gerteisen, Journal of Power Sources. 2013, 233, 358-368.

[55] H. Markotter, R. Alink, J. Haussmann, K. Dittmann, T. Arlt, F. Wieder, C. Totzke, M. Klages, C. Reiter, H. Riesemeier, J. Scholta, D. Gerteisen, J. Banhart, I. Manke, International Journal of Hydrogen Energy. 2012, 37, 7757-7761.

[56] J. Haußmann, H. Markötter, R. Alink, A. Bauder, K. Dittmann, I. Manke, J. Scholta, Journal of Power Sources. 2013, 239, 611-622.

[57] M. P. Manahan, M. C. Hatzell, E. C. Kumbur, M. M. Mench, Journal of Power Sources. 2011, 196, 5573-5582.

[58] T. Sasabe, P. Deevanhxay, S. Tsushima, S. Hirai, Electrochemistry Communications. 2011, 13, 638641.

[59] R. Kuhn, J. Scholta, P. Krueger, C. Hartnig, W. Lehnert, T. Arlt, I. Manke, Journal of Power Sources. 2011, 196, 5231-5239. 